\title{
Procedural Errors in the Evidentiary Process and Their Impact on Criminal Proceedings in the Slovak Republic
}

\author{
Ivana Mokrá1 \\ ${ }^{1}$ Trnava University in Trnava - Faculty of law, Slovakia
}

\begin{abstract}
The lawful procedure in evidentiary process is a conditio sine qua non of the admissibility of evidence. In other words, it is a necessary condition for the admission of evidence in criminal proceedings. The violation of this condition leads to procedural errors leading to the unlawfulness of the evidence, as a result of which the accused may be acquitted. For this reason, it's the aim of this article, not only to define the procedural errors, whose incidence is particularly noticeable in providing evidence by law enforcement authorities involved in criminal proceedings, but also to analyse their impact on the outcome of the criminal proceedings, i.e. the decision about the guilt and punishment of the accused and on the basis of a specific example, to point out shortcomings which would be appropriate to prevent de lege ferenda. The presented article provides, on the one hand, a brief insight into the basic terminology related to the mentioned topic, explains the content and purpose of the legislation and on, the other hand, acquires more practical view, based on an analysis of selected example of procedural error in evidentiary process.
\end{abstract}

Keywords: evidence, means of proof, procedural errors, house search, evidentiary process

\section{Introduction}

Entorf (2012) maintains criminal procedural law is a significant instrument for detecting crime, whereas the quality of evidence provided for the court is crucial for final decision. The author further adds that indictment cannot be successful without properly prepared evidence. From a historical perspective, according to Trubnikova (2015), there is an interesting gradual development of criminal procedural law, which has moved from continental inquisition proceedings to criminal proceeding with an increasing number of 
the elements of Anglo-American contradictory proceedings. Merkel (2014) claims the appointing of a person that is to produce evidence is nowadays often a topic of discussion, while in the past, it was the duty of judges to find evidence and prove guilt of the indicted person.

Ahori et al. (2008) regards evidentiary process as one of the primary steps of criminal proceedings that takes course and relates to all its stages. The author adds the process must aim at revealing the event as it really happened. Iburg (2000) states that the objective of evidentiary process is revealing the facts of the case without reasonable doubts in the scope necessary for a decision. With the help of means of proof and the evidence obtained from them, investigative, prosecuting and adjudicating bodies, possibly with the cooperation with the parties to proceedings, reconstruct the past events, which are the basis for making a decision about the cause of criminal proceedings.

Like the development of criminal law, according to Anastacia (2012), the development of evidence, including its principles, foundations and concepts depending on the nature of criminal proceedings, have logically undergone great many changes. Baranov (2012) states that new types of means of proof have been discovered in the past years. For instance, in the courtrooms of various states audio recordings, audio-visual transmissions or DVD media are used as means of proof. The police use the services of experts in the field of genetics, investigate crime committed (and thus detected) on the Internet, track down the offenders with the help of GPS2 systems, mobile phones, e-mails and use other modern ways.

If certain strict conditions are met, even the recordings of telecommunications traffic may be used as evidence (Cigliano, 2015).

Also, Jiang (2017) believes that evidence and application problems, with which they relate are one of the most frequently discussed topics in the field of criminal procedural law. In the background of the ongoing legislative changes in the criminal law, we can see the relentless effort of legislators to specify the procedure of law enforcement authorities ${ }^{1}$ in the taking of evidence, as well as the way of implementation certain means of proof. Despite this effort, we should not forget the growing number of unlawful practices by providing evidence that result in decreasing the value of evidence, and such vitiating by unlawfulness becomes inadmissible in criminal proceedings (Borkov and Nikolaev, 2020)

Due to a considerable public attention to committing and clarifying crimes, especially due to a better organization and sophistication of offenders, it is the duty of law enforcement authorities to proceed with clarification prudently, consistently and, above all, in accordance with legal regulations. Although their role in criminal proceedings is irreplaceable at every single stage, it is most strongly reflected in the stage of evidentiary process, which forms an immanent part of criminal proceedings. Since the topic of evidentiary process in criminal proceedings is quite extensive, which is well-founded

\footnotetext{
${ }^{1}$ „Law enforcement authorities in criminal proceedings are the public prosecutor and police officer." Provision $\S 10$ section 1 of Criminal Procedural Code
} 
in numerous professional publications, in the following sentences we focus attention to less known issues and procedural errors in criminal proceedings that are causally related to the final court decision about the guilt and the punishment of the accused.

\section{Methods and Data}

From the point of view of the present article as a whole; this article may be viewed as considerably systematic, which is particularly reflected in the application of the generalto-specific procedure. In the first place we applied the literary method through the study of numerous sources and, also, technical articles that gave us a sufficient view on the issue from the theoretical point of view.

In view of the topic, we could not omit the application of the method of analysis, which was particularly reflected in studying the provisions of Criminal Procedural Code as well as European and international standards on fundamental human rights and freedoms, including internal law, which relates to the following topic of procedural errors.

Due to the specific character of the researched problem, we also used the method of comparison with the legal order of the Czech Republic. In the end, it is also possible to notice a certain degree of generalization and a comprehensive assessment of the topic.

\section{The definition of basic concepts examining the topic of evidentiary process}

\section{Evidentiary process, evidence, means of proof}

The definition of the term of evidentiary process could be attributed to a relatively wide range of definitions based on a content, given that this is an area that is frequently discussed by many experts in legal matters. For the purposes of criminal procedural law, evidentiary process means, in particular, the activity of law enforcement authorities in criminal proceedings and the court, according to legal regulations, the aim of which is to become acquainted with the facts relevant for the decision about the guilt and the punishment of the accused (Záhora et al., 2013).

Other juristic literature offers a definition of evidentiary process as a procedural activity, which is carried out in order to reveal, perform, examine, evaluate and, last but not least, use factual data to determine the truth in a criminal case (Vajda, 1996).

However, the above-mentioned activity can be carried out only in accordance with the principles of criminal proceedings, the observance of which is given a huge emphasis and their possible violation would constitute a serious violation of the purpose of criminal proceedings. In this context, we can speak particularly about the principles allocated directly to evidentiary process, whether it is the principle of the presumption of 
innocence, free evaluation of evidence, the principle of the search, immediacy, orality, and at last but not least the principle of the findings of fact beyond reasonable doubt (Šimovček et. al., 2019). Their application in evidentiary process creates a system which reflects effective, fast, but especially lawful clarifying of crimes. Due to the complexity, the evidence tends to be systematically divided into four stages, namely the search for evidence, the execution, the verification and, finally, its assessment.

However, it seems that the evidentiary process is just a kind of thoughtful activity, we should not forget that here is also a practical side of the reflow of account in the particular procedural actions of law enforcement authorities corresponding to the application of means of proof by which we mean mainly interrogating the accused, witnesses, experts, verification of the on-site statement, recognition, reconstruction, investigative experiments, inspection, items and documents relevant to the criminal proceedings, notifications, information obtained through the use of information technology means or means of operative investigative activities. In other words, means of proof can be defined as the tools by which law enforcement authorities obtain evidence.

Evidence is the result of the evidentiary process. Criminal Procedural Code in section 119 (2) states that the evidence can be called „anything that might contribute to the proper clarification of the matter and what was gained from the means of proof may serve as evidence under this Act or under a special Act."2

The only exception to this rule is section119 sub-section 4, Criminal Procedural Code, which mentions the situation of the use of evidence obtained by unlawful coercion or threat of coercion, which can be used as evidence against a person who used such coercion or the threatened coercion. An example of evidence is the testimony of a witness. ${ }^{3}$

Despite several common features of the Czech and Slovak criminal law, it is possible to encounter a different approach to the definition of the term of evidence in criminal proceedings. While the Slovak legislation is based on a contrario for evidence, we cannot consider what is not obtained by means of proof under this Act or a special Act.

There is a fact of importance, whether the evidence obtained by one of the means of proof corresponds to the lawful procedure according to Criminal Procedural Code or another special Act. Lawfulness comes to the fore over the usefulness of clarifying the matter. The Czech criminal law is based on a contrario, in fact, what cannot contribute to the clarification of the matter, does not serve as evidence. In the Czech provision, efficiency takes precedence over lawfulness.

Since the evidentiary process is a complex set of activities consisting of mutually related actions of law enforcement authorities, it is not surprising that their implementation leads to the cases of errors that could significantly affect the outcome of decisions about

2 Provision sec. 119 (2), Criminal Procedural Code

3 Provision sec. 119 (4), Criminal Procedural Code 
the guilt and punishment of the accused. We will deal with them in the following sentences.

\section{Procedural errors in evidentiary process and their impact on criminal proceedings}

In criminal proceedings, the term procedural error occurs in large numbers. Nevertheless, we do not find the meaning of the procedural error and the following synonymous expressions in both juristic publications and legal regulations. In this sense, the legislator failed to provide the legal definition without procedural errors and left the content or examples to the discretion of especially law enforcement authorities and courts. In this respect, in the light of recent case law, such errors are considered the errors in implementation which violate or deconstruct lawful procedure in the pretrial proceedings and its results, or which result in certain acts of the pretrial proceedings that are not accepted as evidence, while it is not possible to remedy these facts in court proceedings.

These include failures to deliver the indictment resolution, the action and decision of noncompetent authority or the authority to be excluded, conducting the proceedings without the victim's consent, although his consent is required by the law, obtaining evidence by unlawful coercion or threat, conducting proceedings without a lawyer, as was the case of compulsory defence and failure to allow the accused or his lawyer to study the files after the end of the preparatory proceedings, insufficient clarification of crimes etc. ${ }^{4}$

Based on the resolution of the Supreme Court of the Slovak Republic in 2014, a procedural error can also be understood as non-compliance with the formal requirements of the procedure and acts in the pretrial proceedings. The regulation of the rights of the defence, the violation of which is demonstratively stated by the law as a procedural error, is based on section 34 sub-section 1, Criminal Procedural Code (rights of the accused) and section 44 sub-section 2, Criminal Procedural Code (rights of a lawyer). ${ }^{5}$

However, it is appropriate to differentiate procedural errors in two levels. In the first level there are substantive procedural errors, the existence of which seriously affects the correctness of the decision on the guilt and punishment of the accused and in the second insignificant procedural errors the occurrence of which does not affect the correctness of the decision (Viktoryová and Blatnický, 2014).

In response to the investigated issues of evidentiary process it is important to focus particular attention on the substantive procedural errors, which affect the use of evidence in criminal proceedings. In this context it is necessary to define two attributes of the use of evidence, namely its admissibility and lawfulness, and in the light of the above, also its effectiveness. The term admissibility can be defined more broadly than the concept of

\footnotetext{
${ }^{4}$ Decision of the Supreme Court of Slovak Republic, File Reference No. 5 Tost 23/2016

${ }^{5}$ Decision of Supreme Court of Slovak Republic, File Reference No. 2 Tost 18/2014
} 
lawfulness because not only does it include lawful evidence (acquired lege artis) but also unlawful (acquired non lege artis).

After looking into section119 sub-section, Criminal Procedural Code, we can only declare the existence of one explicit prohibition on the use of unlawfully obtained evidence in coercion or under the influence of the threat of such coercion, except for the application of such obtained evidence against the person who used the coercion.

In other words, the evidence obtained in the manner described above will be inapplicable procedurally, and, therefore, totally ineffective, and the defect in question is so substantial that it cannot be remedied even afterwards.

However, the application practice and the criminal procedure of law enforcement authorities have also brought about the existence of substantial defects, which are additionally remediable, and the evidence thus obtained can be used in criminal proceedings.

Currently, the possibility of their subsequent correction represents the dividing line between totally ineffective and relatively ineffective evidence. The kind of the procedural error affects the outcome of evidence. However, if it has been stated above that insignificant errors do not affect the correctness of the decision about guilt and punishment of the accused, they even cannot be granted legal consequences in the form of ineffectiveness of evidence (Jalč, 2008).

The impact of the existence of a procedural errors in criminal proceedings is conceived in the Criminal Procedural Code in section 241 subsection 1 paragraph $\mathrm{f}$ ), also in section 244 subsection 1 paragraph $\mathrm{h}$,) which states that „the court shall refuse the indictment and return the matter back to the public prosecutor, if they find serious procedural errors, in particular that the provisions ensuring the rights of the defence counsel were violated."6

Therefore, we cannot talk about any procedural error, but about those which show the significant seriousness of the interference with the right of the accused.

Nevertheless, in the words of the District Court in Pezinok, the new legal regulation also requires the observance of, at least, minimum principles of criminal law in the pretrial proceedings in section 2, Criminal Procedural Code, whose violation must be considered as serious misconduct, as long as its material and processive impact is similar to the violation of the right of the accused. 7 The existence of a procedural error also represents one of the reasons for the revocation of the decision by the Court of Appeals with regards to the following, ,significant in the proceedings that preceded the contested statements of the judgment, particularly because the provisions by which the clarification of the matter should have been provided or the right to defence were violated."

The activity of law enforcement authorities consists of numerous procedural acts leading to the documentation of crimes and the detection of its offenders. Although the report of

\footnotetext{
${ }^{6}$ Provision $\$ 244$ section 1 letter h) of Criminal Procedural Code

${ }^{7}$ Decision of District Court in Pezinok, File Reference No. 1 Pv 1107/08

${ }^{8}$ Provision section 321 subsection 1 paragraph a, Criminal Procedural Code
} 
the Prosecutor General's Office states that the rate of detection and successful punishment of the offenders is increasing, ${ }^{9}$ the number of criminal offenses is also increasing, including procedural errors occurring in the activities of either investigators or prosecutors neglecting the supervisory activities.

One of the reasons for this is the fact that there is a non lege artis procedure in documenting crime that has been committed, which devalues the evidence obtained and thus weakens its applicability or completely excludes it. Such conduct significantly reduces the likelihood of successful punishment of the offender and increases the chances of his release.

In the following example, we will approach the selected means of proof - a house search, the implementation of which is associated with numerous procedural errors by law enforcement authorities, and we will point out its influence on the decision about guilt and sentence of the accused.

\section{House search as a mean of proof}

The home search could be described in the theory of evidentiary process with a focus on the area of criminal procedural law as a special mean of proof. Such a special definition can also be observed in the legislation, which is also included in the legislator, specifically in the fourth chapter of the first part of Criminal Procedural Code, subsumed under the title of seizure of persons and things. Apart from the fact that it is undoubtedly one of the criminal processing institutes, it cannot be denied a criminalistic subtext.

Criminalistics as one of the leading methods of clarifying criminal offenses defines searching as a forensic method, the aim of which is to detain or find persons, things and other facts that are important for the clarification of criminal activity (Šimovček et. al, 2011).

The mentioned institute is very closely connected with the right to privacy as one of the basic human rights enshrined not only in the Constitution of the Slovak Republic Art. 16 (1) or Art. 19 (2) of the second title entitled Fundamental Human Rights and Freedoms, but also corresponds to the European framework for protection in the form of the Convention for the Protection of Human Rights and fundamental Freedoms, simply the European Convention on Human Rights in Article 8, points 1 and 2, including the international standard with emphasis on Art. 17 of the International Covenant on Civil and Political Rights. However, it is not surprising to recall that there is an exception to each rule, and despite this fact it makes no difference.

The use of house search is possible only with a restrictive interpretation of the conditions stipulated by law for its admissibility. ${ }^{10}$

${ }^{9}$ https://www.minv.sk/?tlacove-spravy\&sprava=v-roku-2019-policia-riesila-vyse-58-tisic-trestnych-cinov also CRIME REPORT 2008 - 2019: https://www.surveilligence.com/content/3-vzdelavacie-centrum/2prieskumy/20200227-crime-report-2019/crime-report-2008-2019-by-surveilligence.pdf

${ }^{10}$ In this context, it is possible to draw attention to the decision of the Constitutional Court of the Slovak Republic of March 29, 2006, File Reference No. 97/2006, which stated that the house search is a special 
The use of house searches in criminal proceedings has also been accepted by the European Court of Human Rights, which has stated that states may decide at their discretion on the need for a measure, such as house searches, to obtain material evidence of crime. However, it is necessary that the legislation provides at the same time adequate and sufficient guarantees against abuse (Fryšták, 2015). ${ }^{11}$

A house search, as one of the means of proof, is carried out by law enforcement authorities in criminal proceedings only if it is based on a reasonable suspicion that there is a thing or person in the house, apartment or other space used for housing that is important for the conducted criminal proceedings. This justification of the suspicion must be substantiated by the existence of such facts and information that is able to persuade that the person may have committed a criminal offense (Fryšták, 2015). ${ }^{12}$ It is inconceivable that justification should be based solely on the reliance of law enforcement authorities to find something related to crime. The exact reasons for the use of the house search are also contained of Criminal Procedural Code in section 99 subsection 1 and only for these exemplary reasons it is possible to carry out a house search.

\section{The lawful procedure of performing a house search}

The use of house search itself must be preceded by a consent to perform it, which for the purposes of the law is authorized to be issued by the presiding judge or the judge for the preliminary hearing upon the petition of the public prosecutor. In urgent cases, the following persons are also entitled to act in this manner, the relevant presiding judge and, in the preliminary hearing, the judge for the preliminary hearing, in whose jurisdiction the search is to be performed. ${ }^{13}$

The warrant must be issued in writing with the justification as well. The content page must contain a description of the thing or person to be detained during the house search, provided his identity is known. Subsequently, it shall be delivered to the owner or user of the dwelling during the search and, if this is not possible, no later than 24 hours after the removal of the obstacle that prevented delivery. The person to carry out the enforcement is either the authority that has ordered it or, in most cases, at his order, a police officer. ${ }^{14}$ It should be emphasized that the "house search may be performed only after the prior call of those that such action involves and only if the voluntary release of the sought item or the elimination of the reasons that led to such action cannot be achieved. "15An exception is the

\footnotetext{
intervention in the inviolability of the dwelling and can be carried out only for the purposes of the penitentiary, on the written order of the judge and a person who establishes the law.

${ }^{11}$ Judgment of ECtHR in the Case of Klass and others versus Germany 6 September 1978 (Application no. 5029/71) European Court of Human Rights

12 Judgment of ECtHR in the Case of Fox, Campbell a Hartley versus United Kingdom 30.8. 1990 Appl. No. 12244/86; 12245/86; 12383/86), Council of Europe: European Court of Human Rights, 30 August 1990

13 Provision, section 100 subsection 1 and subsectionsection 2, Criminal Procedural Code

14 Provision, section 100 subsection 1 and subsection 2, Criminal Procedural Code

15 Provision, section 104 subsection 1, Criminal Procedural Code
} 
situation if the call itself would be hindered by an obstacle of a serious character or the call itself could be clearly unsuccessful. 16

One of the important responsibilities of law enforcement authorities in terms of house search is to instruct the persons involved to know the right to carry out the search. Part of the home search is also the obligation of the authority to take an uninvolved person and prove the right to perform the given act. ${ }^{17}$

At the end of the house search, a transcript of the search is made which includes the details. A copy of the transcript shall then be delivered to the person concerned immediately or no later than within 24 hours, together with a written confirmation of the result of the act as well as the inventory of items that have been handed over or seized. ${ }^{18}$

\section{Unlawful procedure of performing a house search}

One of the relatively common procedural errors that can be encountered in the course of implementation in practice during an ongoing investigation with an emphasis on evidentiary process, especially in connection with the performance of house search, is that law enforcement authorities don't inform the involved persons about their right to be present during a house search or they come into the dwelling violently without previous a prior call. In this context, it is possible to refer to the decision of the Supreme Court of the Slovak Republic adopted in 2015. In the subject of the decision, M. Ž. was by a decision of the District Court in Ružomberok convicted of the crime of illicit production of narcotic and psychotropic substances, poisons or precursors, their possession and trafficking in them pursuant to section 172 subsection 1 paragraph c, paragraph $\mathrm{d}$, Criminal Code, while keeping the illicit substance in a room on the ground floor in a family house until a house search was carried out by police officers, when the substance was seized. ${ }^{19}$

For this fact, the district court sentenced him to a 6-year, 6-month and 1-day unconditional imprisonment. The accused filed an appeal, which was rejected by a decision of the Regional Court in Žilina. Subsequently he filed, with a solicitor, an appellate review, in which, according to the discretion of the Supreme Court of the Slovak Republic, he referred to, among others, the reason in section 371 subsection 1 paragraph g; the decision is based on evidence, which was not lawfully performed by the court. $^{20}$

In the appellate review, the accused emphasized the fact that the house search of the family house of his parents, who are also its owners, was not carried out in accordance with the provisions of section 99, et seq., Criminal Procedural Code. It was mainly the fact

\footnotetext{
16 Provision, section 104 subsection 2, Criminal Procedural Code

17 Provision of section105 subsection 1, subsection 2, Criminal Procedural Code

18 Provision of setion 105 subsection 5, Criminal Procedural Code

${ }^{19}$ Decision of Supreme Court of Slovak Republic, File Reference No. 6 Tdo 75/2015

${ }^{20}$ Decision of Supreme Court of Slovak Republic, File Reference No. 6 Tdo 75/2015
} 
that his parents were not informed about the right to participate in the sense of section 105, Criminal Procedural Code; also they were not permitted, even though they were present. ${ }^{21}$ On this factual basis, the accused demanded a remedy for the violation of section 2 subsection 1, Criminal Procedural Code and thus, anyone shall be prosecuted for legitimate reasons and in a manner stipulated by this Act, and a violation of this principle is a significant error in the evidentiary process, with the causal consequence that such evidence is absolutely ineffective and cannot be taken into account in proceedings and decisions. The accused also noted that in the room, where the drugs were found together with the digital scale, he was not present and, moreover, there was no non-participating person whose presence was stated in the transcript on the house search. At the end of the appellate review, he proposed a motion demanding the court to decide about the violation of the law against him, revoke the decision of the regional court, also revoke the decision of the district court, and order the regional court to reconsider and decide the matter to the necessary extent. ${ }^{22}$

The Supreme Court stated that the transcript from the house search made by the order of the judge for the preliminary hearing of the District Court in Ružomberok does not prove that the owners of the family house had been instructed before the house search in terms of their right to participate in the search, which had not been allowed with reference to section 105 subsection 1, Criminal Procedural Code and the transcript of this act was not even signed.

There is no doubt that the investigator, as the person entrusted with the execution of the judge's house search warrant, did not proceed in a lawful manner because the homeowners were not informed about their right to participate in the search, the person did not find out whether this right should be exercised, and the house search was carried out without the participation of the homeowners.

Another procedure of the investigator, which can be described as non lege artis, was the method of entering the building. In the sense of the above and at the same time according to section 106 subsection 2, Criminal Procedural Code, the investigator did not even perform a prior call to the concerned individuals so that they would voluntarily release the item in question, and violently came into the house. ${ }^{23}$

As a result of this unlawful practice, the fundamental human rights and freedoms of the persons have been violated and the necessary extent to achieve the purpose of criminal proceedings has been exceeded, with an impact on the dignity and privacy of persons in the residence at that time.

From the above, it is unmistakable that the house search was conducted unlawfully and, in the house, drugs and digital scale were unlawfully seized, which is in line with the theory of the fruits of the poisonous tree. The content of the theory is based on a legal doctrine, through which legal issues concerning evidence in criminal proceedings are

\footnotetext{
${ }^{21}$ Decision of Supreme Court of Slovak Republic, File Reference No. 6 Tdo 75/2015

22 Decision of Supreme Court of Slovak Republic, File Reference No. 6 Tdo 75/2015

${ }^{23}$ Decision of Supreme Court of Slovak Republic, File Reference No. 6 Tdo 75/2015
} 
resolved on the basis that if primary evidence is deemed unlawful, not only is it impossible to use this primary evidence, but also the secondary evidence, which was obtained on the basis of the primary evidence, in court proceedings. In this case, we could state that if the entrance to the house itself was not lawful, even the evidence, which was subsequently found and secured, is not considered lawful. ${ }^{24}$

The Supreme Court of the Slovak Republic decided on the violation of the law in section 319, Criminal Procedural Code, and section 172 subsection 1 paragraph c, paragraph d, Criminal Code, to the detriment of the accused, revoked the contested decision of the Court of Appeals and the previous decision of the District Court in Ružomberok, and issued an order, as the Court of First Instance, to discuss and decide again. $^{25}$

It is worth noting that the procedure of law enforcement authorities, the supervisory activities of both investigators and prosecutors showed several procedural errors during performing house searches, for example, they failed to inform the residing persons, moreover, they forcibly intruded into the house without a prior call, which resulted in providing unlawful evidence, and the decisions about guilt and punishment of the accused were, together with the subsequent decisions, revoked.

\section{Conclusion}

The evidentiary process and the ensuing criminal procedure institutes are quite often the subject to proactive controversy in connection with the process of obtaining evidence and their subsequent admission in criminal proceedings. There is a noticeable effort by legal experts in the field of criminal law and case law of both national courts and the European Court of Human Rights to define the conditions for the use of individual evidence, which may be affected by procedural defects, which are already mentioned in the previous sentences. However, the amount of evidence is increasing by improving technology (videoconferencing call in the field of interrogation or information technology in interception) and it is, therefore, impossible to define the conditions and draft the legislation of Criminal Procedural Code and related legal rules so that the legislator can assume application problems that may arise in the context of the use of means of proof and subsequent evidence. For this reason, too, the issue of evidentiary process in criminal law is still urgent and current.

The legal closeness of both the Slovak and the Czech regulations of Criminal Procedural Code cannot be neglected. In numerous cases, it is precisely the Czech case law that help the Slovak judges in justifying decisions. In a recent decision of the Supreme Court of the Czech Republic, we have been presented a legal opinion that brought a

\footnotetext{
${ }^{24}$ Despite the Slovak Republic, as a legal entity, adheres to the European / Continental legal culture, the features of the Anglo-American legal culture cannot be denied to it. The principles, the application of which we encounter, are based on Appendix No. IV of the Constitution of the United States of America, provide a protection for both personal and domestic freedom from unauthorized searches in criminal proceedings. ${ }_{25}$ Decision of Supreme Court of Slovak Republic, File Reference No. 6 Tdo 75/2015
} 
breakthrough to the issue of procedural errors as such, distinguishing the distinctive feature of procedural error from the crime of abuse of power by a public official in the form of intent.

The Supreme Court distinguished the procedural errors in terms of culpableness and procedural errors negligent, although there is a violation of the rights of defence of the accused, but the authorities involved in criminal proceedings caused that error unconsciously, and procedural errors deliberately, the dolus (intent) in this case reflects the criminal activity committed by the law enforcement authorities in criminal proceedings in the form of the criminal offense of abuse of power by a public figure according to section 326, Criminal Code, in other words, the violation of the rights of the defence is addressed in this case. ${ }^{26}$

In the report of the Prosecutor General of the Slovak Republic on the activities of the Prosecutor's Office in 2018 and the findings of the Prosecutor's Office on the state of legality in the Slovak Republic, it can be observed, there is an upward trend in the procedural errors of police officers, which mainly consist of the violation the rights of the accused or the victims, the failure to comply with the instructions of the Prosecutor, the shortcomings in the final study of the documents after the completion of the investigation, the failure to interrogate witnesses and victims even after the indictment, the insufficient factual findings or the frequent violations of the provisions on the prosecution of juveniles. In relation to the topic, it has been noted, the authorised members of the Police Force who cannot carry out summary investigation independently and proactively ${ }^{27}$ in the evidentiary process, gained an especially critical perception.

There is a curiosity, it is the fact that in 2018 there was a noticeable upward trend of procedural errors in the activities of police officers, which also corresponds to returning the matter back to the police officers for the completion of the investigation, the intensification of prosecutor supervision would be appropriate, particularly in the area of evidentiary process. Nevertheless, according the 2019 report, the number of the verification of files or the supervision activities of prosecutors concerning respect for legality in criminal matters ${ }^{28}$ decreased.

One of the major attributes, which the Slovak Republic tend to boast of, is the rule of law, among other things, the respect for legislation, in relation to our topic we may specify that mainly in criminal proceedings. Procedural errors and their occurrence in the criminal proceedings have a significant impact on the decision of courts on the guilt and punishment of the accused.

For this reason, the public may often be the witness of an exemption of a potential offender, which may reflect a certain degree of injustice, there is a particular attention to

\footnotetext{
${ }^{26}$ Decision of Supreme Court of Czech Republic File Reference No. N7 Tdo 1121/2018-40

${ }^{27}$ Report of the Prosecutor General of the Slovak Republic on the activities of the Prosecutor's Office in 2018 and the findings of the Prosecutor's Office on the state of legality in the Slovak Republic

${ }^{28}$ Report of the Prosecutor General of the Slovak Republic on the activities of the Prosecutor's Office in 2019 and the findings of the Prosecutor's Office on the state of legality in the Slovak Republic
} 
the victims of criminal acts. And therefore, it is appropriate to consent to the opinion of Oliver Wendell Holmes Jr., a former member of the US Supreme Court, ,, this is court of law, young man, not a court of justice."

\section{References}

Act No. 301/2005 Coll. Criminal Procedural Code of the Slovak Republic.

AHORI, E. et al., 2008. Can neurological evidence help courts assess criminal responsibility? Lessons from law and neuroscience. Year in Cognitive Neuroscience, 1124, p. 145-160.

ANASTACIA, A. P., 2012. Appeal procedure for verifying criminal case sentence by federal law of December 29, 2010: problem perspective. Tomsk State University Journal, 343.

BARANOV, A. A., M. A. BARANOVA and V. F. LUGOVIK, 2017. Influence of the theory and practice on criminal procedure law. Vestnik Tomskogo Gosudarstvennogo Universiteta-Pravo-Tomsk State University Journal of Law, 26, p. 5-13.

BORKOV, V. N. and K. D. NIKOLAEV, 2020. Violation of the rules of qualification cannot compensate loopholes in the criminal law. Vestnik Tomskogo Gosudarstvennogo Universiteta-Pravo-Tomsk State University Journal of Law, 36, p. 30-39.

CIGLIANO, A., 2015. May the principles of restorative justice be applied to international criminal law? 2nd International Conference on Education and Social Sciences (INTCESS), p. 1301-1304.

Crime report 2008 - 2019, 2019. Online, available from https://www.surveilligence.com/content/3-vzdelavacie-centrum/2prieskumy/20200227-crime-report-2019/crime-report-2008-2019-bysurveilligence.pdf.

SLOVAKIA, 2009. Decision of District Court in Pezinok, File Reference No. 1 Pv 1107/08.

CZECH REPUBLIC, 2018. Decision of Supreme Court of Czech Republic, File Reference No. N7 Tdo 1121/2018-40.

SLOVAKIA. Decision of Supreme Court of Slovak Republic, File Reference No. 2 Tost $18 / 20147$.

SLOVAKIA. Decision of Supreme Court of Slovak Republic, File Reference No. 5 Tost $23 / 2016$.

SLOVAKIA. Decision of Supreme Court of Slovak Republic, File Reference No. 6 Tdo 75/2015.

ENTORF, H., 2012. Expected recidivism among young offenders: Comparing specific deterrence under juvenile and adult criminal law. European Journal of Political Economy, 28(4), p. 414-429. 
Evaluation of statistical indicators of crime for the year 2019, 2019. Online, available from https://www.minv.sk/?tlacove-spravy\&sprava=v-roku-2019-policia-riesila-vyse-58tisic-trestnych-cinov.

FRYŠTÁK, M., 2015. Dokazovaní v prípravnem řízení [Evidence in preliminary processes]. 2. ed. Brno: Masaryk university.

IBURG, U., 2000. Practical problems concerning the criminal law of prevention of cruelty to animals. Deutsche Tierarztliche Wochenschrift, 107(3), p. 88-91.

JALČ, A., 2008. Teoretické a praktické otázky dokazovania v trestnom konaní [Theoretical and practical issues in criminal acts]. Bratislava: EUROUNION.

JIANG, CH., 2017. The research on forensic DNA evidence base on criminal law vision. Proceedings of the 7th international conference on management, education, information and control, 156, p. 9-14.

UNITED KINGDOM, 1990. Judgment of ECtHR in the Case of Fox, Campbell a Hartley, 30.8. 1990 Appl. No. 12244/86; 12245/86; 12383/86), Council of Europe: European Court of Human Rights, 30 August 1990.

GERMANY, 1978. Judgment of ECtHR in the Case of Klass and others, 6 September 1978 (Application no. 5029/71) European Court of Human Rights.

MERKEL, R., 2014. Neuroimaging and Criminal Law. Monatsschrift fur Kriminologie und Strafrechtsreform, 97(5-6), p. 365-386.

SLOVAKIA, 2018. Report of the Prosecutor General of the Slovak Republic on the activities of the Prosecutor's Office in 2018 and the findings of the Prosecutor's Office on the state of legality in the Slovak Republic.

SLOVAKIA, 2018. Report of the Prosecutor General of the Slovak Republic on the activities of the Prosecutor's Office in 2019 and the findings of the Prosecutor's Office on the state of legality in the Slovak Republic.

ŠIMOVČEK, I., et al., 2011. Kriminalistika [Criminalistics]. Plzeň: Aleš Čenek.

ŠIMOVČEK, I., et al., 2019. Trestné právo procesné [Process criminal law]. 3. ed. Plzeň: Aleš Čeněk.

TRUBNIKOVA, T. V., 2015. Prohibition to use the data obtained in consequence of crime provocation as one of the elements of the right to judicial protection and the guarantees for its realization in criminal law of the Russian Federation. Vestnik Tomskogo Gosudarstvennogo Universiteta-Pravo-Tomsk State University Journal of Law, 16(2), p. 109-127.

VAJDA, L., 1996. Teoretické východiská a praktické aspekty dokazovania vo vyšetrovaní [Theoretical founations and practical aspects of evidence in investigation]. Bratislava: Akadémia Policajného zboru v Bratislave.

VIKTORYOVÁ, J. and J. BLATNICKÝ, 2014. Procesné chyby v dokazovaní [Process mistakes in evidence] In: Záhora ed. Aktuálne problémy prípravného konania trestného: zborník 
DOI: https://doi.org/10.36708/Littera_Scripta2020/2/9

príspevkov z celoštátnej vedeckej konferencie s medzinárodnou účastou konanej dňa 3. apríla 2014. Prague: Leges, p. 119-133.

ZÁHORA, J., et al., 2013. Dokazovanie v trestnom konaní [Evidence in criminal act]. 1. ed. Prague: Leges.

\section{Contact address of the author:}

Bc. Ivana Mokrá, Trnava University in Trnava - Faculty of law, Kollárova 545/10, 91701 Trnava, Slovakia, e-mail: mokra.ivana@gmail.com 